\title{
Molecular Differentiation of Angiostrongylus costaricensis, $A$. cantonensis, and $A$. vasorum by Polymerase Chain Reaction- Restriction Fragment Length Polymorphism
}

\author{
Roberta L Caldeira, Omar S Carvalho ${ }^{+}$, Cristiane LFG Mendonça, Carlos Graeff-Teixeira*, \\ Márcia CF Silva*, Renata Ben*, Rafael Maurer*, Walter S Lima**, Henrique L Lenzi***
}

Laboratório de Helmintoses Intestinais, Centro de Pesquisas René Rachou-Fiocruz, Av. Augusto de Lima 1715, 30190-002 Belo Horizonte, MG, Brasil * Laboratório de Parasitologia Molecular e Biologia de Parasitas, Pontifícia Universidade Católica do Rio Grande do Sul, Porto Alegre, RS, Brasil **Departamento de Parasitologia, Instituto de Ciências Biológicas,

Universidade Federal de Minas Gerais, Belo Horizonte, MG, Brasil ***Departamento de Patologia, Instituto Oswaldo CruzFiocruz, Rio de Janeiro, RJ, Brasil

Angiostrongylus cantonensis, A. costaricensis, and A. vasorum are etiologic agents of human parasitic diseases. Their identification, at present, is only possible by examining the adult worm after a 40-day period following infection of vertebrate hosts with the third-stage larvae. In order to obtain a diagnostic tool to differentiate larvae and adult worm from the three referred species, polymerase chain reaction-restriction fragment length polymorphism was carried out. The rDNA second internal transcribed spacer (ITS2) and mtDNA cytochrome oxidase I regions were amplified, followed by digestion of fragments with the restriction enzymes RsaI, HapII, AluI, HaeIII, DdeI and ClaI. The enzymes RsaI and $\mathrm{Clal}$ exhibited the most discriminating profiles for the differentiation of the regions COI of mtDNA and ITS2 of rDNA respectively. The methodology using such regions proved to be efficient for the specific differentiation of the three species of Angiostrongylus under study.

Key words: Angiostrongylus - polymerase chain reaction - restriction fragment length polymorphism - second internal transcribed spacer - cytochrome oxidase I

Angiostrongylus (Nematoda: Angiostrongylidae) parasites may be found in the lungs and arteries of insectivores, rodents, canines, and felines (Anderson 1978). Some of these parasites may reach man as a definitive host, causing serious public health problems such as: eosinophilic meningitis caused by A. cantonensis (Alicata 1988), abdominal angiostrongyliasis by $A$. costaricensis (Moreira \& Cespedes 1971), and diseases of the central nervous system by A. vasorum (Eckert \& Lämmler 1972).

Rodents are definitive hosts of $A$. cantonensis and $A$. costaricensis, whereas A. vasorum is a canine parasite. A wide variety of molluscs are intermediate hosts of such angiostrongylids that are frequently confused with other nematodes (Ash 1970).

The occurrence of such parasites in humans emphasizes the importance of a precise differentiation among species. However, the specific identification of larvae and adult worms concerning Angiostrongylus genus based on morphological characters is unfeasible due to vague and similar descriptions on size and body shapes among species (Santos 1985, Ubelaker 1986). Indeed, correct morphological identification has been also precluded as

Partial financial support: Fapemig and Fiocruz

Corresponding author. Fax: +55-31-3295.3115. E-mail: omar@cpqrr.fiocruz.br

Received 24 July 2003

Accepted 5 November 2003 an accurate diagnostic tool for many other organisms in which polymerase chain reaction together with restriction fragment length polymorphism (PCR-RFLP) have been used. This methodology provides an alternative approach for molecular differentiation and has been successfully employed to identify Biomphalaria snails (Caldeira et al. 2000, Vidigal et al. 2000), to distinct cryptic species within the Trypanosoma brucei group (Agbo et al. 2001) and also to separate closely related nematodes (Newton et al. 1998, Gasser et al. 1999, Wu et al. 1999, Otranto et al. 2001). In addition, sequencing of the second internal transcribed spacer region (ITS2), as well as PCR-RFLP has shown to be a powerful genetic tool for studying some Metastrongylidae species (Leignel et al. 1997, Conole et al. 1999).

The aim of the current study was to develop an appropriate methodology based on PCR-RFLP of the mitochondrial-derived cytochrome oxidase I gene (COI) and the genomic DNA based ITS2 of rDNA in order to differentiate $A$. costaricensis, A. cantonensis, and $A$. vasorum. These molecular markers were chosen based on their usefulness for discrimination of closely related species (Brown et al. 1979, Hillis \& Dixon 1991). In addition, RFLP patterns from Aelurostrongylus abstrusus were compared with such species due to their taxonomic closeness with the genus Angiostrongylus.

\section{MATERIALS AND METHODS}

Parasites and DNA extraction - Adult worms as well as first and third-larval stages of A. costaricensis, $A$. cantonensis, and $A$. vasorum, kept under laboratory conditions, were used (Table). A. abstrusus was included 
in the study in order to provide restriction pattern data for further comparison with Angiostrongylus, due to their closeness. Adult worms were recovered from several sites of vertebrate hosts (lungs and mesenteric arteries); the first-larval stage was collected from feces of vertebrate hosts and the third-larval stage was obtained after pepsin digestion of the slug Sarasinula marginata. All parasites under study were sent to the Intestinal Helminthiasis Laboratory of René Rachou Research Center, Fiocruz (Brazil), in 70\% ethanol solution, except for the specimens of A. cantonensis, which were sent lyophilized. Total DNA was extracted from worms and pools of larvae, using the phenol-chloroform method as described by Simpson et al. (1982).

mtDNA COI amplification - A portion of the COI region was amplified using LCO (forward; 5'GGTCAACAAATCATAAAGATATTGG-3') and HCO (reverse; 5'-TAAACTTCAGGGTGACCAAAAAATCA$\left.3^{\prime}\right)$ as primers. These primers were designed upon evolutionarily conserved regions of the COI sequence (Folmer et al. 1994). PCR amplification was undertaken in a total volume of $10 \mu \mathrm{l}$ consisting of: 1-10 ng of template DNA, 10 mM Tris-HCl, pH 8.5, $200 \mu \mathrm{M}$ each dNTP, $1.5 \mathrm{mM}$ $\mathrm{MgCl}_{2}, 0.8 \mathrm{U}$ of Taq DNA polymerase (Cenbiot, RS, Brazil), $50 \mathrm{mM} \mathrm{KCl}$, together with $0.3 \mathrm{pmol}$ of each primer. The reactions were covered with a drop of mineral oil and subjected to the following cycle program: initial denaturation step for $5 \mathrm{~min}$ at $95^{\circ} \mathrm{C}$, and then 40 cycles as follows: annealing at $50^{\circ} \mathrm{C}$ for $1 \mathrm{~min}$, extension at $72^{\circ} \mathrm{C}$ for $2 \mathrm{~min}$, denaturation at $95^{\circ} \mathrm{C}$ for $45 \mathrm{~s}$ and a final extension step at $72^{\circ} \mathrm{C}$ for $5 \mathrm{~min}$.

rDNA ITS2 amplification - The ITS2 region was amplified using the primers NC1 (forward; 5'ACGTCTGGTTCAGGGTTGTT-3') and NC2 (reverse;
5'-TTAGTTTCTTTTCCTCCGCT-3') (Gasser et al. 1993) and PCR reaction was carried out as described above. The conditions in a thermocycler were: initial denaturation step for $90 \mathrm{~s}$ at $94^{\circ} \mathrm{C}$, and then 39 cycles for: annealing at $58^{\circ} \mathrm{C}$ for $1 \mathrm{~min}$, extension at $72^{\circ} \mathrm{C}$ for $90 \mathrm{~s}$, denaturation at $94^{\circ} \mathrm{C}$ for $50 \mathrm{~s}$ and a final extension step at $72^{\circ} \mathrm{C}$ for $10 \mathrm{~min}$.

For both amplifications, a negative control (no template DNA) was included in all experiments. Three microliters of the amplified products were visualized on $6 \%$ silver stained polyacrylamide gels to have the quality of amplification checked.

RFLP analysis -The PCR products were diluted in water, divided into $10 \mu \mathrm{l}$ aliquots and then separately digested with different restriction endonucleases. Such endonucleases were randomly selected once COI and ITS2 sequences from Angiostrongylus are not available in the GeneBank. Six restriction enzymes were used: four base cutters RsaI, HapII, AluI, and HaeIII; the five base cutter $D d e \mathrm{I}$ and the six base cutter ClaI. Ten to 12 units of each enzyme were used for each digestion reaction, together with $1 \mu \mathrm{l}$ of the respective enzyme buffer and $10 \mu \mathrm{l}$ of the diluted amplification product. The digestion was performed for $3.5 \mathrm{~h}$ at $37^{\circ} \mathrm{C}$ and products were evaluated by visualization on $6 \%$ silver stained polyacrylamide gels, after phenol/chloroform extraction to remove protein. The results were recorded with a digital photodocumentation system (Mavica, Sony). A control of activity for each enzyme was performed by digesting $150 \mathrm{ng}$ of pUC18 simultaneously with the samples under evaluation.

\section{RESULTS}

$m t D N A C O I$ - The amplification generated a fragment of approximately $700 \mathrm{bp}$. After enzyme digestion, all samples had their profiles reproduced and only some specimens of

TABLE

Species, stage of development, host, geographical origin, and laboratory of origin

\begin{tabular}{|c|c|c|c|c|c|}
\hline Species & $\begin{array}{l}\text { Stage of } \\
\text { development }\end{array}$ & $\begin{array}{l}\text { Number of } \\
\text { samples }\end{array}$ & Host & $\begin{array}{l}\text { Geographical } \\
\text { origin }\end{array}$ & Laboratory of origin \\
\hline \multirow{7}{*}{$\begin{array}{l}\text { Angiostrongylus } \\
\text { costaricensis }\end{array}$} & Adult & 5 & Mus musculus & \multirow{2}{*}{$\begin{array}{l}\text { Crissiumal/RS } \\
\text { Brazil }\end{array}$} & \multirow{2}{*}{$\begin{array}{l}\text { Department of Pathology, } \\
\text { Oswaldo Cruz Institute, } \\
\text { Rio de Janeiro, Brazil }\end{array}$} \\
\hline & Third-larval stage & Pool & Sarasinula marginata & & \\
\hline & \multirow{5}{*}{ First-larval stage } & \multirow{5}{*}{ Pool } & \multirow{5}{*}{ M. musculus } & Santa Rosa/RS & Laboratory of Molecular \\
\hline & & & & Brazil & Parasitology and Parasite \\
\hline & & & & & Biology, Pontifical \\
\hline & & & & & Catholic University, \\
\hline & & & & & Rio Grande do Sul, Brazil \\
\hline \multirow[t]{3}{*}{ A. cantonensis } & \multirow[t]{3}{*}{ Adult } & \multirow[t]{3}{*}{5} & \multirow[t]{3}{*}{ Rattus norvergicus } & Akita/Japão & Department of Parasitology, \\
\hline & & & & & Medical School, Akita \\
\hline & & & & & University, Japan \\
\hline \multirow[t]{3}{*}{ A. vasorum } & Adult & 5 & \multirow[t]{3}{*}{ Canis familiaris } & Caratinga/MG & \multirow{3}{*}{$\begin{array}{l}\text { Department of Parasitology, } \\
\text { Institute of Biological } \\
\text { Science, Federal University } \\
\text { of Minas Gerais, Brazil }\end{array}$} \\
\hline & & & & Brazil & \\
\hline & First-larval stage & Pool & & & \\
\hline \multirow{4}{*}{$\begin{array}{l}\text { Aelurostrongylus } \\
\text { abstrusus }\end{array}$} & \multirow[t]{4}{*}{ First-larval stage } & \multirow[t]{4}{*}{ Pool } & \multirow[t]{4}{*}{ Felis catus } & Belo Horizonte/MG & Department of Parasitology, \\
\hline & & & & Brazil & Institute of Biological \\
\hline & & & & & Science, Federal University \\
\hline & & & & & of Minas Gerais, Brazil \\
\hline
\end{tabular}


each species are demonstrated here. Out of the six enzymes, only HaeIII showed no restriction sites in the amplified fragment (data not shown). Through the other enzymes, it was possible to distinguish among the species under study (data not shown) and $R s a I$ presented the best profile for differentiating worms and larvae (Fig. 1).

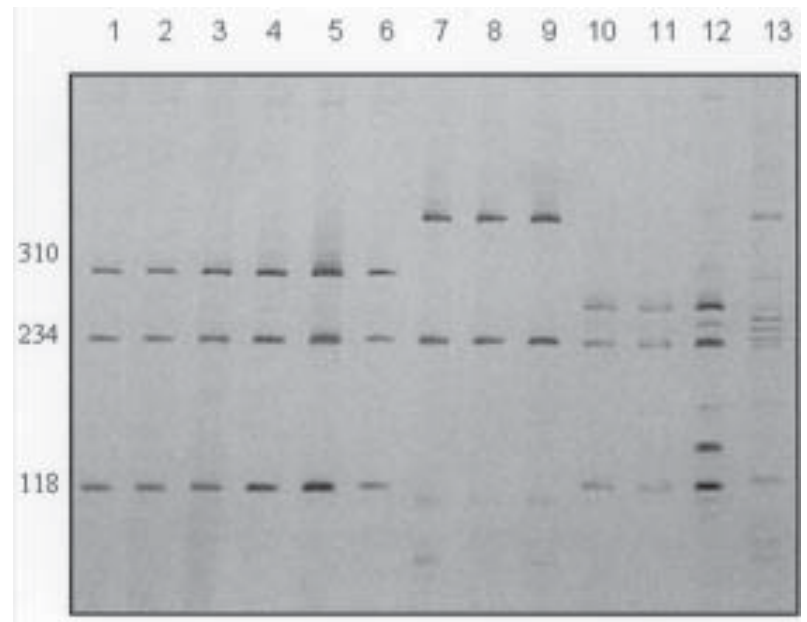

Fig. 1: silver-stained $6 \%$ polyacrylamide gel showing the restriction fragment length polymorphism profiles obtained by digesting the cytocrome oxidase I with RsaI enzyme from Angiostrongylus costaricensis: Santa Rosa, Rio Grande do Sul, Brazil - first-larval stage (lanes 1-3); Crissiumal, Rio Grande do Sul, Brazil - third-larval stage (lane 4); adult worm (lanes 5, 6); A. cantonensis: Akita, Japan - adult worm (lanes 7-9); A. vasorum: Caratinga, Minas Gerais, Brazil - adult worm (lanes 10, 11) and first-larval stage (lane 12); Aelurostrongylus abstrusus: Belo Horizonte, Minas Gerais, Brazil first-larval stage (lane 13). Molecular size markers are shown on the left side of the figure.

rDNA ITS2 - PCR amplification yielded fragments ranging from $600 \mathrm{bp}$ (A. costaricensis and A. vasorum) to 650 bp (A. cantonensis). After enzyme digestion all samples exhibited reproducible profile and only some specimens of each species are shown here. DdeI enzyme presented no restriction sites for the species under study (data not shown); HaeIII, AluI, and $M n l \mathrm{I}$ also showed no restriction sites for $A$. cantonensis and A. vasorum (data not shown). The profiles produced by $R s a$ I allowed us to distinguish among the three species, however A. costaricensis and A. vasorum genetic profiles showed to be alike. ClaI enzyme exhibited the best profile for differentiating the worms and larvae (Fig. 2).

The restriction patterns for some species were complex and the sum of sizes of the bands produced upon digestion was not equal to the size of the undigested PCR products. For instance, in the patterns produced by $R s a \mathrm{I}$ for A. vasorum (Fig. 1) the sum of the sizes of two bands $(180+72 \mathrm{pb})$ was not equal to the estimated $600 \mathrm{pb}$. It might be due to overlapping of similar size fragments produced by the enzyme.

\section{DISCUSSION}

The present study, using molecular markers, allowed us to differentiate the larvae and adult worms from $A$. costaricensis, A. cantonensis, and A. vasorum, con-

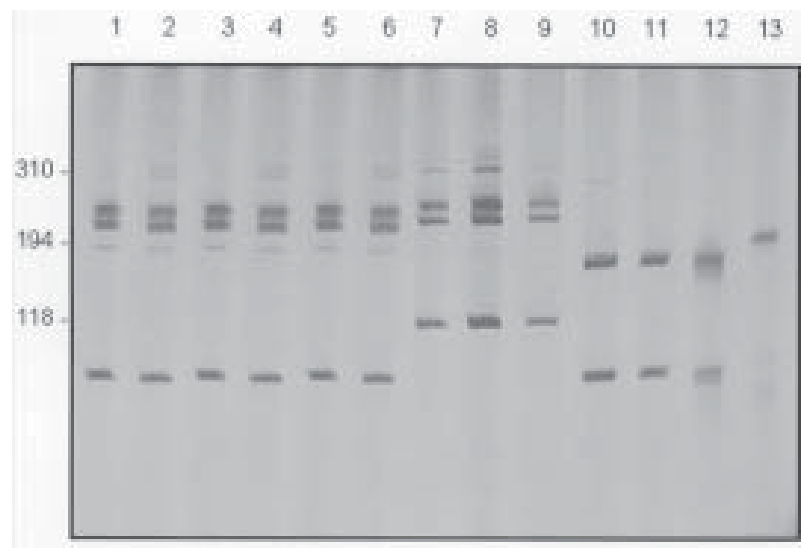

Fig. 2: silver-stained $6 \%$ polyacrylamide gel showing the restriction fragment length polymorphism profiles obtained by digesting the rDNA internal transcribed spacer 2 with $\mathrm{ClaI}$ enzyme. Series of lanes for this figure is the same as for Fig. 1. Molecular size markers are shown on the left side of the figure.

tributing to reduce time-consuming morphological identification, which usually takes around 40 days. Routinely, for parasite identification, third-stage larvae are isolated from naturally infected snails and further used for oral infection of vertebrate hosts. After adult worm maturation and migration to the final habitat, they are then recovered and morphologically analyzed. This usual procedure, besides being a long lasting process, requires the sacrifice of the vertebrate host to have the adult worms recovered.

The importance of fast and accurate diagnostic tools for diseases caused by nematodes lies on knowledge enhancement on prevalence and geographical distribution, as such parasites have nearly all gastropods as their intermediate hosts. Humans are accidental hosts, who does not eliminate eggs or larvae in the feces, and serological diagnoses show low sensitivity and specificity (Graeff-Teixeira et al. 1997, Geiger et al. 2001). Unfortunately, there is no definitive diagnosis for humans and the infection rates may be underestimated.

Efforts have been made in order to enlarge studies on nematodes of medical and veterinarian importance. Gasser and Newton (2000) reported genomic and genetic investigations on bursate nematodes and remarked that although PCR-RFLP is widely used for several nematodes, it has been little utilized in studies on strongylidae. Most works on Nematoda have chosen rDNA regions because they are useful genetic markers for studies on diagnosis, systematics, molecular evolution, and many other aspects. Thus, the application of molecular markers is widely used to differentiate closely related species and in many cases only a target region is used, depending on the proposed aim. All regions of the nuclear and mitochondrial genomes of parasites accumulate mutations over time and some regions are more accessible to nucleotide alterations than others (Gasser 1999). Anderson (2001), studying Ascaris epidemiological aspects, showed how molecular data, derived from a single DNA region, might lead to ambiguous conclusions. 
Therefore, in order to support our evidence, two distinct DNA regions were chosen, which provided us with convergent and consistent results. Furthermore, no intraspecific variation was detected in the regions ITS2 and COI, except for the larvae pool of A. vasorum (Fig. 1, lane 12), which presented a slight polymorphism in the COI region. This proposal is supported by the fact that there is a substantial variation in intra and interpopulational mtDNA as remarked by Tarrant et al. (1992) and Blouin et al. (1998). The ITS2 region exhibited few restriction sites regarding the applied enzymes used here. Out of six, only RsaI and ClaI found restriction sites for all species under study. Such data are in accordance with those by Romstad et al. (1998) who reported little or no variation in ITS2 sequences for strongylidae nematodes. Hoste et al. (1995) have also reported no variation in ITS2 sequences in Trichostrongylus eggs and/or worms. However, in both studies, the differences observed among species clearly exceeded the level of intraspecific variation, which reinforce the use of ITS2 region sequences to differentiate closely related species. On the other hand, Leignel et al. (1997) and Conole et al. (1999) reported a significant level of inter and intraspecific variations in the ITS2 sequences for Metastrongylus sister group of Angiostrongylidae. The primers set NC1-NC2 is known to amplify ITS2 from a variety of nematodes but not from other nematode groups or vertebrate host DNA (Newton et al. 1997, Hung et al. 1999). Preliminary studies, in our laboratory, showed that specific PCR directed to the regions ITS2 and COI from rDNA and mtDNA, respectively, for the following snails $S$. marginata, $S$. linguaeformis, and Biomphalaria glabrata, produced no fragments that overlapped those from nematodes studied here.

In the present study, PCR-RFLP showed to be a fast and accurate diagnostic tool to Angiostrongylus of medical and veterinarian importance. Both genetic regions, ITS2 and COI, yielded satisfactory results considering the proposed aim. The most appropriate restriction enzymes for ITS2 of rDNA and COI of mtDNA were ClaI and $R s a \mathrm{I}$, respectively. As already stressed, PCR-RFLP methodology has the advantage of producing clear and distinct profiles for each species.

\section{ACKNOWLEDGMENTS}

To Dr Kentaro Yoshimura, Department of Parasitology, Medical School of University of Akita, Japan, for providing us with Angiostrongylus cantonensis; Joziana Barçante, Department of Parasitology of Federal University of Minas Gerais, Brazil, for maintaining the life cycle of A. vasorum; Ester Maria Mota, Department of Pathology, Oswaldo Cruz Institute-Fiocruz, Rio de Janeiro, Brazil, for being in charge of A. costaricensis life cycle.

\section{REFERENCES}

Agbo EC, Majiwa PAO, Claassen JHM, Roos MH 2001. Measure of molecular diversity within the Trypanosoma brucei brucei and Trypanosoma brucei gambiense as revealed by genotypic characterization. Exp Parasitol 99: 123-131.

Alicata JE 1988. Angiostrongyliasis cantonensis (eosinophilic meningitis): historical events in its recognition as a new parasitic disease of man. $J$ Wash Acad Sci 78: 38-46.
Anderson RC 1978. Keys to the genera of the superfamily Metastrongyloidea. In RC Anderson, AG Chabaud, S Willmont (eds), C.I.H. Keys to the Nematode Parasites of Vertebrates, No. 5, Commonwealth Agricultural Bureaux, Farnham Royal, Bucks, 40 pp.

Anderson TJC 2001. The dangers of using single locus markers in parasite epidemiology: Ascaris as a case study. Trends Parasitol 17: 183-188.

Ash LR 1970. Diagnostic morphology of the third-stage larvae of Angiostrongylus cantonensis, Angiostrongylus vasorum, Aelurostrongylus abstrusus, and Anafilaroides rotratus (Nematoda: Metastrongyloidea). J Parasitol 56: 249-253.

Blouin MS, Yowell CA, Courtney CH, Dame JB 1998. Substitution bias, rapid saturation, and the use of mtDNA for nematode systematics. Mol Biol Evol 15: 1719-1727.

Brown WM, George Jr M, Wilson AC 1979. Rapid evolution of animal mitochondrial DNA. Proc Natl Acad Sci USA 17: 1967-1971.

Caldeira RL, Vidigal THDA, Matinella L, Simpson AJG, Carvalho OS 2000. Identification of planorbids from Venezuela by polymerase chain reaction amplification and restriction fragment length polymorphism of internal transcribed spacer of the RNA ribosomal gene. Mem Inst Oswaldo Cruz 95: 171-177.

Conole JC, Chilton NB, Jarvis T, Gasser RB 1999. Intraspecific and interspecific variation in the second internal transcribed spacer (ITS2) sequence for Metastrongylus (Nematoda: Metastrongyloidea) detected by high resolution PCR-RFLP. Int J Parasitol 30: 655-658.

Eckert J, Lammler G 1972. Angiostrongylose bei Mensch und Tier. Z Parasitol 39: 303-322.

Folmer O, Black M, Hoeh W, Lutz R, Vrijenhoek R 1994. DNA primers for amplification of mitochondrial cytochrome $c$ oxidase subunit I from diverse metazoan invertebrates. Mol Mar Biol Biot 3: 294-299.

Gasser RB 1999. PCR-based technology in veterinary parasitology. Vet Parasitol 84: 229-258.

Gasser RB, Newton SE 2000. Genomic and genetic research on bursate nematodes: significance, implications, and prospects. Int J Parasitol 30: 509-534.

Gasser RB, Chilton NB, Hoste H, Beveridge I 1993. Rapid sequencing of rDNA from single worms and eggs of parasitic helminths. Nucleic Acids Res 21: 2525-2526.

Gasser RB, Woods WG, Huffman MA, Blotkamp J, Polderman AM 1999. Molecular separation of Oesopagostomum stephanostomum and Oesophagostomum bifurcum (Nematoda: Strongyloidea) form non-human primates. Int J Parasitol 29: 1087-1091.

Geiger SM, Laitano AC, Sievers-Tostes C, Agostini AA, SchulzKey H, Graeff-Teixeira C 2001. Detection of the acute phase of abdominal angiostrongyliasis with a parasite-specific IgG enzyme linked immunosorbent assay. Mem Inst Oswaldo Cruz 96: 515-518.

Graeff-Teixeira C, Agostini AA, Camillo-Coura L, Ferreirada-Cruz MF 1997. Seroepidemiology of abdominal angiostrongyliasis: the standardization of an immunoenzymatic assay and prevalence of antibodies in two localities in Southern Brazil. Trop Med Int Health 2: 254-260.

Hillis DM, Dixon MT 1991. Ribosomal DNA: molecular evolution and phylogenetic inference. Quart Rev Biol 66: 411-453.

Hoste H, Chilton NB, Gasser RB, Beveridge I 1995. Differences in the second internal transcribed spacer (ribosomal DNA) between five species of Trichostrongylus (Nematoda: Trichostrongylidae ). Int J Parasitol 25: 75-80.

Hung CG, Gasser RB, Beveridge I, Chilton NB 1999. Species- 
specific amplification by PCR of ribosomal DNA from some equine strongyles. Parasitology 119: 69-80.

Leignel V, Humbert JF, Elard L 1997. Study by ribosomal DNA ITS2 sequencing and RAPD analysis on the systematics of four Metastrongylus species (Nematoda: Metastrongyloidea). J Parasitol 83: 608-611.

Morera P, Céspedes R 1971. Angiostrongylus costaricensis n. sp. (Nematoda: Metastrongyloidea), a new lungworm occurring in man in Costa Rica. Rev Biol Trop 18: 173-185.

Newton LA, Chilton NB, Beveridge I, Hoste H, Nansen P, Gasser RB 1998. Genetic markers of strongylid nematodes of livestock defined by PCR-based restriction analysis of spacer rDNA. Acta Trop 69: 1-15.

Newton LA, Chilton NB, Monti JR, Bjorn H, Várady M, Christensen CM, Gasser RB 1997. Rapid PCR-based delineation of the porcine nodular worms, Oesophagostomum dentatum and $O$. quadrispinutalatum. Mol and Cel Probes 11: 149-153.

Otranto D, Tarsitano E, Giangaspero A, De Luca F, Puccini V 2001. Differentiation among three species of bovine Thelazia (Nematoda: Thelaziidae) by polymerase chain reactionrestriction fragment length polymorphism of the first internal transcribed spacer ITS1 (rDNA). Int J Parasitol 31: 1693-1698.
Romstad A, Gasser RB, Nansen P, Polderman AM, Chilton NB 1998. Necator americanus (Nematoda: Ancylostomatidae) from Africa and Malaysia have different ITS2 rDNA sequences. Int J Parasitol 28: 611-615.

Santos CP 1985. Redescrição de Angiostrongylus (Parastrongylus) costaricensis isolado de novo hospedeiro silvestre, Proechimys sp., na Venezuela (Metastrongyloidea, Angiostrongylidae). Mem Inst Oswaldo Cruz 80: 81-83.

Simpson AJG, Sher A, McCutchan TF 1982. The genome of Schistosoma mansoni: its size, bases and repetitive sequences. Mol Biochem Parasitol 6: 125-137.

Tarrant CA, Blouin MS, Yowell CA, Dame JB 1992. Suitability of mitochondrial-DNA for assaying interindividual geneticvariation in small helminths. J Parasitol 78: 374-378.

Ubelaker JE 1986. Systematics of species referred to the genus Angiostrongylus. J Parasitol 72: 237-44.

Vidigal THDA, Caldeira RL, Simpson AJG, Carvalho OS 2000. Further studies on the molecular systematics of Biomphalaria snails from Brazil. Mem Inst Oswaldo Cruz 95: 57-66.

Wu Z, Nagano I, Pozio E, Takahashi Y 1999. Polymerase chain reaction-restriction fragment length polymorphism (PCRRFLP) for the identification of Trichinella isolates. Parasitology 118: 211-218. 